\title{
Metabolic syndrome: new therapeutic approaches
}

\author{
Claudia Della Corte, Valerio Nobili* \\ From 70th Congress of the Italian Society of Pediatrics, Joint National Meeting SIP, SICUPP, SITIP \\ Palermo, Italy. 11-14 June 2014
}

In the last three decades in the United States the prevalence of overweight/obesity in pediatric population has more than tripled, causing the onset also in pediatric age of diseases previously considered exclusively of adults, such as metabolic syndrome (MetS) [1]. MetS represents a cluster of cardiometabolic abnormalities, including visceral obesity, dyslipidemia, hypertension and diabetes mellitus type 2 (T2DM) (Table 1). The prevalence of pediatric MetS ranged from $2 \%$ to $9 \%$ in the general population and from $12 \%$ to $44 \%$ in obese children, depending of definition used [1]. Several evidences suggest that the metabolic derangements observed in children may have a worrisome repercussion early on their health in adulthood $[2,3]$.

Lifestyle modification, represented by the association among regular physical exercise and a balanced diet appropriate for age, is the most important therapeutic approach in children and adolescent with obesity and risk factors for MetS [4]. Behavioral intervention is mandatory but, in many cases, it is difficult to achieve or not sufficient and most pediatric patients require pharmacologic therapy early in their disease course. At the present time, the vast majority of drugs needed to treat insulin-resistance, hypercholesterolemia, hypertension are off-label in pediatric setting, although several studies demonstrated that pharmacological treatment for pediatric obesity and its related comorbidities are necessary [5].

Regarding dyslipidemia, the use of oral statins is reserved for children older than 10 years of age that, while on diet, continue to have dyslipidemia associated to family history for early cardiovascular disease (CVD) or additional risk factors.

Metformin is the only drug approved for treatment of impaired fasting glucose (IFG) or impaired glucose tolerance (IGT) in children. Several studies demonstrated its efficacy in ameliorating gluco-insulinemic profile; moreover, it has been reported a moderately effect on body weight in obese children.

Table 1 Diagnostic criteria for metabolic syndrome in children and adolescents

\begin{tabular}{|c|c|c|c|}
\hline \multirow[b]{2}{*}{ Age (years) } & \multicolumn{3}{|r|}{ IDF criteria } \\
\hline & $6-9$ & $10-15$ & $>15$ (adult criteria) \\
\hline $\begin{array}{l}\text { Waist } \\
\text { circumference }\end{array}$ & $\begin{array}{l}\geq 90^{\text {th }} \text { percentile for age (MS as } \\
\text { entity is not diagnosed) }\end{array}$ & $\begin{array}{l}\geq 90^{\text {th }} \text { percentile or adult } \\
\text { cut-off if lower }\end{array}$ & $\begin{array}{l}\geq 94 \mathrm{~cm} \text { for males, } \\
\geq 80 \mathrm{~cm} \text { for females }\end{array}$ \\
\hline $\begin{array}{l}\text { Blood } \\
\text { pressure }\end{array}$ & & $\begin{array}{c}\text { Systolic } \geq 130 \text { or } \\
\text { diastolic } \geq 85 \mathrm{mmHg}\end{array}$ & $\begin{array}{c}\text { Systolic } \geq 130 \text { or diastolic } \geq 85 \mathrm{mmHg} \text { or treatment of previously } \\
\text { diagnosed hypertension }\end{array}$ \\
\hline Triglycerides & & $\begin{array}{l}\geq 1.7 \mathrm{mmol} / \mathrm{L}(\geq 150 \mathrm{mg} / \\
\mathrm{dL})\end{array}$ & $\geq 1.7 \mathrm{mmol} / \mathrm{l}$ ( $\geq 150 \mathrm{mg} / \mathrm{dL}$ )or specific treatment for high triglycerides \\
\hline $\mathrm{HDL}-\mathrm{C}$ & & $\begin{array}{l}<1.03 \mathrm{mmol} / \mathrm{L}(<40 \\
\mathrm{mg} / \mathrm{dL})\end{array}$ & $\begin{array}{c}<1.03 \mathrm{mmol} / \mathrm{L}(<40 \mathrm{mg} / \mathrm{dL}) \text { in male and } 1.29 \mathrm{mmol} / \mathrm{L}(<50 \mathrm{mg} / \mathrm{dL}) \text { in } \\
\text { females or specific treatment for low HDL-C }\end{array}$ \\
\hline $\begin{array}{l}\text { Fasting } \\
\text { glucose }\end{array}$ & & $5.6 \mathrm{mmol} / \mathrm{l}(100 \mathrm{mg} / \mathrm{dL})$ & $5.6 \mathrm{mmol} / \mathrm{l}(100 \mathrm{mg} / \mathrm{dL})$ or known T2DM \\
\hline
\end{tabular}

IDF: International Diabetes Federation

HDL Cholesterol: High-density lipoprotein cholesterol

\footnotetext{
* Correspondence: nobili66@yahoo.it

Hepatometabolic Department, "Bambino Gesù" Children's Hospital, S. Onofrio

Square, 4, 00165, Rome, Italy
} 
Anti-hypertensive drugs, such as angiotensin-converting-enzyme inhibitors (ACEIs), angiotensin-receptor blockers (ARBs), calcium channel blockers (CCBs), and beta-blocking agents are used in pediatric patients and the choice of drug class is made on the basis of clinical characteristics of the single patient.

The core of treatment of pediatric MetS is abdominal obesity. Currently no pharmacological approach to obesity is accepted for pediatric patients. Bariatric surgery has been considered a successful treatment for MetS in obese adults in term of weight loss and decrease of mortality rate. This procedure has been used also in carefully selected obese adolescents and the outcomes seem to be similar to those for adults. However, further studies are needed to better select the patients to surgically treat and define efficacy and safety of bariatric surgery in pediatric MetS.

Published: 11 August 2014

\section{References}

1. Ogden $\mathrm{CL}$, Carroll MD, Flegal KM: High body mass index for age among US children and adolescents, 2003-2006. JAMA 2008, 299:2401-5.

2. Olshansky SJ, Passaro DJ, Hershow RC, Layden J, Carnes BA, Brody J, Hayflick L, Butler RN, Allison DB, Ludwig DS: A potential decline in life expectancy in the United States in the $21^{\text {st }}$ century. N Engl J Med 2005, 352:1138-1145.

3. Alley DE, Chang WW: The changing relationship of obesity and disability, 1988-2004. JAMA 2007, 298:2020-7.

4. Steinberger J, Daniels SR, Eckel RH, Hayman L, Lustig RH, McCrindle B, Mietus-Snyder ML, American Heart Association Atherosclerosis, Hypertension, and Obesity in the Young Committee of the Council on Cardiovascular Disease in the Young; Council on Cardiovascular Nursing and Council on Nutrition, Physical Activity, and Metabolism: Progress and challenges in metabolic syndrome in children and adolescents: a scientific statement from the American Heart Association Atherosclerosis, Hypertension, and Obesity in the Young Committee of the Council on Cardiovascular Disease in the Young; Council on Cardiovascular Nursing; and Council on Nutrition, Physical Activity, and Metabolism. Circulation 2009, 119:628-647.

5. D'Adamo E, Santoro N, Caprio S: Metabolic syndrome in pediatrics: old concepts revised, new concepts discussed. Pediatr Clin N Am 2011, 58:1241-1255.

doi:10.1186/1824-7288-40-S1-A48

Cite this article as: Della Corte and Nobili: Metabolic syndrome: new therapeutic approaches. Italian Journal of Pediatrics 2014 40(Suppl 1):A48.

\section{Submit your next manuscript to BioMed Central and take full advantage of:}

- Convenient online submission

- Thorough peer review

- No space constraints or color figure charges

- Immediate publication on acceptance

- Inclusion in PubMed, CAS, Scopus and Google Scholar

- Research which is freely available for redistribution

Submit your manuscript at www.biomedcentral.com/submit
C Biomed Central 